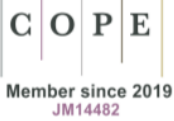

Grzegorz Michalski*

\title{
0 zachowaniu pamięci historycznej pierwszej połowy XX wieku. Wprowadzenie do rozważań o przeszłości oświaty
}

\begin{abstract}
Abstrakt
W kontekście rozważań o momentach przełomowych w dziejach Polski pierwszej połowy wieku XX omówiono zawartość tomu czasopisma „Nauki o Wychowaniu. Studia Interdyscyplinarne" będącego świadectwem zachowania o nich pamięci historycznej.
\end{abstract}

Słowa kluczowe: momenty przełomowe, wiek XX, pamięć historyczna.

\section{On Preserving the Historical Memory of the First Half of the 20th Century. Introduction to Considerations about the Past of Education}

\begin{abstract}
In the context of reflections on the breakthrough moments in the history of Poland in the first half of the 20th century, the content of the volume of the journal "Nauki o Wychowaniu. Studia Interdyscyplinarne" (Educational Sciences. Interdisciplinary Studies) which testifies to the preservation of their historical memory, is discussed.
\end{abstract}

Keywords: breakthrough moments, 20th century, historical memory.

Pierwsze pięćdziesiąt lat wieku XX było dla społeczeństwa polskiego okresem zróżnicowanym - zmagań z zaborcami i walki o wolną Polskę w okresie Wielkiej Wojny, później stabilizacji oraz w miarę spokojnego funkcjonowania w warunkach niepodległego państwa, następnie udziału w obronie kraju i troski o przetrwanie

\footnotetext{
* Uniwersytet Łódzki, Wydział Nauk o Wychowaniu, Katedra Historii Wychowania i Pedeutologii. Artykuł otrzymano: 8.06.2020; akceptacja: 8.06.2020.
} 
pod hitlerowską okupacją, wreszcie konieczności odnalezienia się w państwie uzależnionym w swoim bycie od decyzji władz Związku Sowieckiego. Warto zauważyć, że życie państw i narodów zawsze przebiegało w cyklach determinowanych sytuacją wewnętrzną bądź uwarunkowaniami zewnętrznymi. Innymi słowy, czasy względnego status quo występowały naprzemiennie z porami przełomów. Ustalony stan rzeczy nie oznaczał nigdy, zresztą zawsze z różnych powodów, pełnej zgody i akceptacji na jego trwanie przez wszystkie grupy społeczne, co stawało się przyczyną występowania „podziemnych” i zwykle mało widocznych dla większości nurtów kontestujących istniejącą rzeczywistość. Z kolei czasy przełomów, głównie politycznych, występujące zwykle jako konsekwencje powolnego nawarstwiania się licznych, wcześniej niedostrzeganych lub nierozwiązywanych kwestii społecznych po przekroczeniu granicznego punktu prowadziły do protestów, manifestowania niezadowolenia, powstań, rewolucji, zamachów stanu czy wojen.

Należy podkreślić, że przełom jest pojęciem neutralnym i wskazuje jedynie na nieuchronne nastąpienie zmiany, która w zależności od dziejowych okoliczności przynosić może realizację przez dane zbiorowości oczekiwanych nowych rozwiązań albo przyczyniać się do konieczności urzeczywistniania narzuconego, nie zawsze akceptowanego przez większość, obcego planu. W tym kontekście dla społeczeństwa polskiego pierwsza połowa wieku XX zapisała się dwoma wielkimi momentami przełomowymi - pierwszą wojną światową, w wyniku której Polska odrodziła się jako niepodległy kraj, i drugą wojną światową, której zakończenie oznaczało znalezienie się w strefie wpływów państwa radzieckiego.

Początek dwudziestego stulecia nie zapowiadał jeszcze powrotu Polski na mapy Europy. Ziemie polskie nadal znajdowały się pod panowaniem trzech mocarstw, które określały granice wszelkich przejawów życia społecznego, w tym również oświaty. W zaborze pruskim nasilający się ucisk eliminował ze szkolnictwa ostatnie już symboliczne oznaki polskości poprzez zakaz nauczania religii w języku ojczystym. W Królestwie Polskim miał miejsce krótki moment odwilży politycznej, jaki nastąpił po rewolucji 1905 r., otwierając większe możliwości dla rozwoju prasy, stowarzyszeń czy dopuszczania w szkołach języka polskiego. Nadana jeszcze w poprzednim wieku przez władze austriackie autonomia Galicji gwarantowała mieszkańcom stosunkowo rozległe, w porównaniu do innych zaborów, uprawnienia tworzenia i organizowania w wielu zakresach własnej codzienności. Powstanie w 1918 r., po 123 latach niewoli, niepodległego państwa polskiego stworzyło sprzyjające warunki do budowania i rozwijania szeroko pojętej oświaty, opartej na rodzimej kulturze. Przerwanego wybuchem drugiej wojny światowej bujnego rozwoju piśmiennictwa oświatowego i edukacyjnego, funkcjonowania licznych instytucji oraz towarzystw pedagogicznych i nauczycielskich nie udało się odtworzyć po 1945 r. w podobnej formie i postaci. Sytuacja polityczna spowodowała, że do głosu doszły wówczas wzorce oparte na obcych ideałach i wartościach.

Spojrzenie z perspektywy czasu na polską oświatę w pierwszej połowie XX w. pozwala wyrazić ogólniejszej natury pogląd, że zdarzenia przełomów politycznych 
odegrały swoistą rolę w nadawaniu jej coraz to innego kształtu. W okresie Drugiej Rzeczypospolitej wprowadzano szereg nowatorskich $\mathrm{w}$ tym obszarze rozwiązań, ale jednocześnie nie odrzucono wcześniejszego, własnego dorobku z okresu zaborów. Odwoływano się do niego, rozwijano zamieszczone w nim myśli i twórczo go pomnażano. Inaczej sytuacja wyglądała po drugiej wojnie światowej, kiedy to zdecydowanie starano się odciąć od osiągnięć niedawnej przeszłości, implementując ostatecznie rozwiązania obce dla świata polskiej kultury i tradycji.

Co prawda przeszłość jest czasem minionym i wydaje się zupełnie niewidoczna, jednak nie oznacza to, że nie istnieje. Z jednej strony powszechnie funkcjonuje ona $\mathrm{w}$ różnych formach pamięci indywidualnej i społecznej (Szacka 2000: 14), z drugiej natomiast - ulokowała się bezpiecznie w postaci dokumentów i zapisków, a także wytworów aktywności wydawniczej w takich miejscach, jak archiwa, muzea i biblioteki (Borowiec 2013: 181). Kwerendy nad przeszłością posiadają kluczowe znaczenie dla rozwoju nauk o wychowaniu. Pozostawiając na uboczu potencjalne zarzuty ze strony tych, którzy nie zauważają, a nawet zaprzeczają historyczności uwarunkowań zjawisk i przebiegu procesów edukacyjnych, można sformułować dający się bez trudu uzasadnić pogląd, że sięganie w badaniach pedagogicznych do szeroko rozumianej definicyjnie przeszłości oświatowej nie jest wyłącznie podtrzymywaniem pamięci „czasu wygasłego”, lecz stanowi imperatyw metodologiczny, gdyż - wskazywał Czesław Majorek - każde współczesne zjawisko czy też wydarzenie pedagogiczne posiada swoiste dla niego antecedencje w minionych już latach i wymaga określenia jego źródeł i genezy (Majorek 1995: 60). Zgadzając się $\mathrm{z}$ tak rozumianą perspektywą tworzenia wiedzy, Romuald Grzybowski napisał:

Tak jak pamięć o dziedzictwie kulturowym i duchowym kształtuje świadomość narodową, tak pamięć o dziedzictwie edukacyjnym kształtuje tożsamość pedagogów i samej pedagogiki. Bez znajomości dziedzictwa edukacyjnego trudno też kreować kolejne odmiany «nowego wychowania», czy też marzyć o «wychowaniu na miarę czasów» (Grzybowski 2011: 26).

Z kolei zastanawiając się nad problemem relacji między historią i pedagogiką, W. Szulakiewicz prezentuje pogląd, że do kategorii, która zbliża i łączy obie dyscypliny, należy przede wszystkim pojęcie pamięci. Nazywając je obrazowo pomostem, stwierdza:

Nawet pobieżna analiza historiografii pedagogicznej wykazuje, że możemy wymienić co najmniej trzy płaszczyzny związków pamięci i pedagogiki, a są to:

- pamięć o źródłach historyczno-pedagogicznych,

- źródła historyczne jako medium pamięci o różnych obszarach pedagogiki,

- pamięć o twórcach, ideach i instytucjach zdeponowana w źródłach historycznych (Szulakiewicz 2016: 10-11). 
Należy zauważyć, że w odróżnieniu od badań sensu stricto historycznych projekty historycznych kwerend w pedagogice zdecydowanie wykraczają poza cele poznawcze, ponieważ studia retrospektywne dotyczące różnych obszarów minionej rzeczywistości oświatowej i edukacyjnej stanowią odpowiedź na ważne aktualnie wyzwania pedagogiczne. W perspektywie takiego sposobu myślenia o roli badań historii wychowania jako jednej z subdyscyplin pedagogicznych można umiejscowić zamieszczone rozprawy i artykuły w niniejszym tomie czasopisma „Nauki o Wychowaniu. Studia Interdyscyplinarne". Każdy z nich odtwarza i analizuje pewien niewielki wycinek nieznanych albo jeszcze nie do końca odkrytych przejawów życia społecznego pierwszej połowy wieku XX. Poświadcza tym samym zasadę o niedających się wymazać z pedagogiki śladów pamięci historycznej, która na stałe została utrwalona $\mathrm{w}$ różnych rodzajach piśmiennictwa oraz dokumentach archiwalnych.

W dziale „Studia i rozprawy” znajdują się teksty omawiające w ujęciu chronologicznym kilka zagadnień. W oparciu o analizę piśmiennictwa Warszawskiego Towarzystwa Higienicznego z początków wieku XX A. Bołdyrew ukazała specyfikę podejścia lekarzy i higienistów do ważnych życiowych problemów ówczesnej młodzieży. Sprawy związane $\mathrm{w}$ tym czasie $\mathrm{z}$ edukacją dziewcząt podjęły dwie autorki. Iwonna Michalska wykazała, że wydawany w latach 1905-1906 periodyk „Świat Kobiecy” przywiązywał duże znaczenie nie tylko do alfabetyzacji młodzieży płci żeńskiej, ale także do jej dalszego, ale formalnie zorganizowanego kształcenia, natomiast Małgorzata Krakowiak po przeanalizowaniu warszawskich czasopism dla kobiet z lat 1907-1918 doszła do wniosku, że odrębność ich profilów ideowych - od konserwatywnych po progresywne - wyraźnie wpływała na zróżnicowany przekaz, kierowany do czytelniczek, nie tylko o miejscu kobiety w społeczeństwie, ale też o zakresie i stopniu wykształcenia dziewcząt. Odmienną problematyką zajęła się Renata Bednarz-Grzybek, dokładnie przybliżając zalecane na łamach „Naszych Zdrojów” (1910-1914) formy aktywnego wypoczynku kuracjuszy w czasie wolnym od zabiegów terapeutycznych. Grzegorz Michalski poddał kwerendzie wydawane w okresie Wielkiej Wojny czasopisma pedagogiczne organizacji nauczycielskich w kontekście ich wkładu do rozwoju rodzimych i upowszechniania międzynarodowych koncepcji edukacyjnych oraz projektowania rozwiązań przyszłego w kraju ustroju szkolnictwa. Z kolei Wiesław Jamrożek w dalece zsyntetyzowanej formie przypomniał dorobek polskiej myśli pedagogicznej i praktyki edukacyjnej okresu międzywojennego. Joanna Sosnowska po dokonaniu wyczerpujących studiów nad polskim piśmiennictwem z lat 1918-1939 zaprezentowała zakres zainteresowania w tym czasie teorią pedagogiczną Marii Montessori i jej recepcją w wychowaniu przedszkolnym. Eleonora Sapia-Drewniak z jednej strony ukazała początki czasopiśmiennictwa andragogicznego w ostatnich latach XIX stulecia, z drugiej natomiast - scharakteryzowała wszystkie ogólnopolskie periodyki tego typu wydawane w Drugiej Rzeczypospolitej. Katarzyna Dormus przypomina okoliczności powstania oraz działalność Studium Pedagogicznego Uniwersy- 
tetu Jagiellońskiego, które zainicjowało powstanie w Krakowie wpływowego akademickiego ośrodka badań naukowych w dziedzinie pedagogiki.

Na kolejny dział „Prace z warsztatu” składa się 9 minimonografii będących rezultatem dociekań nad zawartością różnych wydawnictw ciągłych oraz eksploracji zasobów archiwalnych. 0 propagowanych formach krzewienia oświaty na wsi na łamach czasopism społeczno-kulturalnych Królestwa Polskiego z lat 1905-1918 napisała w swym opracowaniu Joanna Falkowska. Z jej rozważań można dowiedzieć się, że twórcy tych pism przede wszystkim zwracali uwagę na potrzebę zakładania bibliotek, powoływania do życia szkół różnego typu, kształcenia nauczycieli szkół ludowych, zrzeszania się młodzieży oraz edukacji kobiet. Natomiast o zachęcaniu międzywojennych nauczycieli do odejścia od tradycyjnych metod nauczania i wychowania wydobył na ten temat treści z „Ruchu Pedagogicznego” Ryszard Ślęczka, omawiając koncepcje nowoczesnej edukacji autorstwa między innymi Johna Deweya, Georga Kerschensteinera, Heleny Parkhurst, Owidiusza J. Decroly'ego i Rudolfa Steinera. Z kolei ze skrupulatnie przeprowadzonych archiwalnych dociekań nad działalnością Szkoły Powszechnej w Łopiennie w latach 1918-1939 Katarzyna Kabacińska-Łuczak nakreśliła obraz inspirowanej ideami nowego wychowania aktywności społeczno-kulturalnej tej niewielkiej wiejskiej szkoły na rzecz najbliższego środowiska. W tym samym nurcie propagowania pedagogiki reform utrzymany jest tekst Elżbiety Dolaty i Elżbiety Magiery. Pierwsza autorka, zapoznaje czytelników z proponowanymi przez „Wychowanie Przedszkolne" nowatorskimi metodami i formami pracy wychowawczej, zapewniającymi swobodny rozwój każdemu dziecku, druga - przedstawia międzywojenną Komisję Kół Krajoznawczych Młodzieży Szkolnej: okoliczności powstania tej organizacji, podstawy jej funkcjonowania oraz kierunki działalności. 0 tym, jak organizowano praktykę szkolnego wychowania państwowego i obywatelskiego w warunkach wdrażania w życie ustawy oświatowej z 1932 r. wiedzę na ten temat, pozyskaną z zachowanych dokumentów Państwowego Gimnazjum Męskiego im. A. Mickiewicza w Wilnie, przekazuje Stefania Walasek. Przedmiotem zainteresowania ostatnich dwóch opracowań jest zagadnienie edukacji zawodowej. W pierwszym Danuta Kocurek przybliżyła zawartość miesięcznika „Szkoła Zawodowa” (1926-1935) koncentrującą się głównie na informowaniu o działalności szkół zawodowych w Polsce i poza jej granicami, programach kształcenia zawodowego, podręcznikach i kursach dokształcających, w drugim - Kamila Cybulska nakreśliła zarys dziejów Radomskiego Towarzystwa Kursów Technicznych (1927-1939), prywatnej instytucji oświatowej zajmującej się dokształcaniem zawodowym dorosłych, która stała się w tym mieście wyjątkowym miejscem wymiany wiedzy i umiejętności praktycznych między instytucjami oświatowymi a przedsiębiorstwami przemysłowymi.

Rubrykę „Dyskusje/Polemiki” wypełnia tekst Anety Bołdyrew, który jest rzeczową analizą i oceną książki Sylwii Kuźmy-Markowskiej pt. Dziecko, rodzina i płeć $w$ amerykańskich inicjatywach humanitarnych i filantropijnych w II Rzeczypospolitej opublikowanej przez Wydawnictwo Uniwersytetu Warszawskiego. 
Łamy niniejszego tomu czasopisma „Nauki o Wychowaniu. Studia Interdyscyplinarne" zamyka szkic Łukasza Kalisza o osiągnięciach białostockiego ośrodka historii wychowania i przygotowanej z okazji jego 40-lecia konferencji naukowej nt. „Dziecko w historii - między godnością a zniewoleniem”.

\section{Bibliografia}

Borowiec P. (2013) Czas polityczny po rewolucji. Czas w polskim dyskursie politycznym po 1989 roku, Kraków, Wydawnictwo Uniwersytetu Jagiellońskiego.

Grzybowski R. (2011) Dziedzictwo edukacyjne przeszłości: balast czy skarbnica wiedzy? w: Przełomy edukacyjne. Dziedzictwo polskiej teorii i praktyki, W. Szulakiewicz (red.), Toruń, Wydawnictwo Adam Marszałek, s. 21-33.

Majorek Cz. (1995) Warsztat badawczy historyka wychowania dziejów najnowszych w: Stan i perspektywy historii wychowania, W. Jamrożek (red.), Poznań, Wydawnictwo „Eruditus”, s. 55-70.

Szacka B. (2000) Pamięć zbiorowa i wojna, „Przegląd Socjologiczny”, z. 2, t. 49, s. 11-28.

Szulakiewicz W. (2016) Przedmowa. Pamięć i przeszłość w: Umieszczeni w przeszłości. Pamięć w naukach pedagogicznych, W. Szulakiewicz (red.), Toruń, Wydawnictwo Naukowe Uniwersytetu Mikołaja Kopernika, s. 7-11. 